\title{
DEMOCRACY AND POLITICAL GOVERNANCE IN SOUTH AFRICA: TWO DECADES AFTER APARTHEID
}

\author{
Mpfariseni Budeli*
}

\begin{abstract}
South Africa was under the apartheid rule for around fifty years. Apartheid was formally established by the National Party when it came to power in 1948. In terms of the apartheid policy, the government belonged to the White people who enjoyed all human rights and were entitled to rule the country to the detriment of the Black people despite the latter constituting the overwhelming majority of the population. The apartheid regime eventually came to an end in the early 1990s. Following the ending of the dictatorial regime, a new Constitution was adopted and the first democratic elections were held in South Africa. [T] his paper reflects on the road that South Africans have gone from Apartheid to democracy and good political governance, on what they have achieved as well as the challenges and prospects for democratic governance in the country.
\end{abstract}

Keywords: South Africa; apartheid; Constitution; governance; democracy and human rights.

\section{Introduction}

South Africa is a former British colony. It became independent in 1910 as the Union of South Africa. Apartheid was established by the National Party when it gets into power in 1948. Apartheid entrenched racial discrimination by reserving citizenship and rights to participate in government affairs for the White minority while the Black people who constitute the overwhelming majority of the population were denied most human rights, including political rights. ${ }^{1}$

* Mpfariseni Budeli is a professor in the College of Law, University of South Africa. She holds an LLB, LLM (UNIN) and PhD (UCT).

1 Blacks in South Africa were for a long time denied human rights such as the right to form and join political parties and to participate in the activities of those political parties, freedom of association, freedom of assembly, freedom of movement. 
Gradually, [a]partheid came to be regarded by the international community as a crime against humanity and many instruments were passed by the United Nations to censure apartheid. ${ }^{2}$ The South African Native National Congress was established in 1912 and takes the lead in anti-apartheid movement. ${ }^{3}$ Other anti-apartheid organisations were created such as the Pan Africanist Congress $(\mathrm{PAC})^{4}$ and Azanian People's Organisation (AZAPO). ${ }^{5}$ The apartheid regime reacted to this anti-apartheid movement by issuing banning order, while their leaders were arrested, detained and sentenced to prison. However, the struggle against apartheid continued unabated.

In the late 1980s and early 1990s, domestic and international pressure became more intense, forcing the apartheid government to unban anti-apartheid organisations and unconditionally release all political prisoners, including Nelson Mandela who then became the President of South Africa after spending 27 years in prison. The National Party government then embarked on the process of political negotiation. All-party negotiations formally began within the Convention for a Democratic South Africa (CODESA) which was convened on 20 December 1991. The Convention ended with the adoption of an interim Constitution in 1991 followed by the first democratic elections which were held in 1994, participated by all South Africans.

Almost two decades have lapsed since then. South Africa has made tremendous progress and stands today as one of the shining examples of democracy and good political governance particularly in the African region and the world in general. However, South Africa is still facing several challenges that need to be overcome by their people to consolidate democracy and good political governance.

Against this background, the present paper reflects on the road that South Africans have pass by namely, from Apartheid to democracy and good political governance, the challenges they face and prospects

\footnotetext{
For example, the United Nations (UN) adopted the International Convention against Apartheid in sports in 1985.

3 The South African Native National Congress transformed into the African National Congress (ANC) in 1923.

4 The PAC was formed in 1959.

5 AZAPO was formed in 1978.
} 
for democratic governance in South Africa two decades after the end of apartheid. This writing will first revisits the concepts of democracy and good political governance briefly as they are central to this reflection. The struggle of the South African to eradicate apartheid until the establishment of a constitutional and democratic rule is revisited. It also highlights the achievements, stresses the challenges and the prospects for democratic consolidation.

\section{Revisiting the Concepts of Democracy and Political Governance}

Democracy and governance seem to qualify as and fit into Gallie's description of "essentially contested concepts". ${ }^{6}$ Democracy and governance are "complex" concepts. Definitions of 'democracy' are abundant, contentious, and very often vague. Finally, "What is Democracy" and "What is governance"? It is imperative that I be as precise as possible about these concepts and how they are understood in this paper, the dialectic existing between, and their relationship.

\section{Democracy}

Ronen pointed out that "[d]efining democracy is a challenge". Many scholars have spent their lifetimes teasing out the subtleties and nuances associated with democracy.

Democracy has come to be a catchall term and it is undoubtedly the most discussed and contested notion of political theory. ${ }^{8}$ Nwabueze pointed out that "[n]o word is more susceptible of a variety of tendentious interpretations than democracy". ${ }^{9}$

Walter B. Gallie, quoted by Gordon J. Schochet, "Introduction: Constitutionalism, Liberalism, and the Study of Politics", in Constitutionalism, ed. Roland J. Pennock and William J. Chapman (New York: New York University Press, 1979) 6.

7 Dov Ronen, "The Challenge of Democracy in Africa: Some Introductory Observations", in Democracy and Pluralism in Africa, ed. Dov Ronen (London: Hodder and Stoughton, 1986) 1.

8 John Hoffman, State, Power and Democracy: Contentious Concepts in Practical Political Theory (New York: St. Martins Press, 1988) 31.

9 Benjamin O. Nwabueze, Constitutionalism in the Emergent States (London :C Hurst \& Co, 1973) 1. 
According to Sono,

Throughout history the ideal of democracy has been the mother of all mischief. No concept has spawned such a multitude of devotees as democracy, however contradictorily conceived; nor has one, in the annals of political theory and conduct, been as disfigured, debased, and distorted as this one. Social scientists have twisted the meaning of the concept, while the other brotherhood, professional politicians and party hacks, misrepresented the concept in practice to the degree that its expression has been profoundly, wholly and permanently cast in a different hue all too foreign to its basic meaning. ${ }^{10}$

As Wiseman held,

Many governments of quite different types wish to describe themselves as democratic. In some cases the term has even been incorporated into the official name of the state... although it is a noticeable paradox that in most cases where this happened (e.g. the German Democratic Republic, the People's Democratic Republic of Yemen, or in Africa, the Democratic Republic of Congo), the States concerned appear significantly undemocratic. ${ }^{11}$

Democracy has acquired different, even contradictory meanings. It has been suffering as much from its loyal partisans as from its opponents. Even its fierce enemies, dictators and authoritarian leaders, claim to be democrats and proclaim their faith in "democracy". There is a widespread agreement that democracy is "a good thing". Everywhere in the world, the term "democratic" almost inevitably connotes praise, while "undemocratic" implies censure. ${ }^{12}$

10 John A. Wiseman, Democracy in Black Africa. Survival and Revival (New York: Paragon House Publishers, 1990) 4.

11 Ibid.

12 Francois Venter, Constitutional Comparison (The Netherlands: Kluwer Law International, 2000) 193. 
Democracy is derived from two Greek words; namely demos and kratos meaning people and power or authority respectively. ${ }^{13}$ It entails that individuals should be free and equal in the determination of the conditions of their own lives. They should enjoy rights despite being subject to duties. Democracy is based on the belief that all people should have the same basic rights and freedoms and that people should be free to govern themselves. Democracy implies that the people should have the final say with regard to how they are to be governed. Concepts such as rule of law, separation of powers and limited government are all factors contributing to the achievement of democracy.

Scholars have already spilled too much ink on the definition of democracy. Depending on the scope of democracy, two of its major conceptions may be identified, namely the minimalist and maximalist conceptions. These conceptions have been informed by the two dominant ideologies in the contemporary world, namely liberalism/capitalism and socialism/communism. Minimalist and maximalist conceptions of democracy are generally opposed in the scientific discourse. ${ }^{14}$

Whilst minimalist scholars define democracy as a process and a set of institutions and focus on political democracy, maximalist concepts concentrate on the substance and values of democracy, the most prominent among them being social equality, and socioeconomic rights.

In maximalists' view, democracy is essentially socio-economic and popular or socialist democracy. Theirs is a very broad definition

13 Wiseman 1996, 1-14; Richard L. Sklar, "African Politics: The Next Generation," in State, Conflict, and Democracy in Africa, ed. Richard Joseph (Lynne Rienner publishers, 1999) 166; Julius E. Nyang'oro, "Discourses on Democracy in Africa: An Introduction," in Discourses on Democracy: Africa in Comparative Perspective, ed. Nyang'oro (Tanzania: Dar-es-Salaam University Press, 1996) X; Björn Beckman, "Whose Democracy? Bourgeois versus Popular Democracy", Review of African Political Economy (1989) 84-98; Issa G. Shivji, "State and Constitutionalism: A New Democratic Perspective", in State and Constitutionalism: An African Debate on Democracy, ed. Issa G. Shivji (Harare: SAPES, 1991) 27-65.

14 Wiseman The New Struggle for Democracy at p9. 
of democracy that would include some or all of the desirable political, social, and economic characteristics of a "good society". ${ }^{15}$

The specific form that democracy takes in any country is largely determined by prevailing political, social and economic circumstances and is influenced by historical, traditional and cultural factors.

Hence, democracy can also be direct or indirect. In a direct democracy, citizens vote on government decisions and make or reject laws for their communities. For indirect democracy on the other hand, government by the people is through their freely elected representatives and this is what is called representative democracy.

My view of democracy is both formal and substantive, implying both formal and substantive equality and emphasising individual, civil, political and collective and socio-economic rights. Individual and civil rights are not simply "bourgeois" values and do matter in democracy, however defined. ${ }^{16}$ Yet, democracy should not stop there, at forms, institutions, individual and civil and political rights, since it is not only a set of principles or institutions, but also of values.

As Bangura rightly put it;

Although democracy is primarily concerned with the rules and institutions that allow for open competition and participation in government, it embodies also social and economic characteristics that are crucial in determining its capacity to survive. ${ }^{17}$

Formal democracy must be linked to more substantive forms of popular rule. ${ }^{18}$ There is not necessarily a conflict

\footnotetext{
15 See Glaser D, "Discourses of Democracy in the South African Left: A Critical Commentary", in Nyang'oro op cit 248-251; Sandbrook R, "Liberal Democracy in Africa: A Socialist-Revisionist Perspective", in Nyang'oro op cit 145. See also Mangu AMB, The Road to Constitutionalism and Democracy in Post-Colonial Africa: The Case of the Democratic Republic of Congo (2002) UNISA at 186.

16 Bangura Y, "Authoritarian Rule and Democracy in Africa: A Theoretical Discourse", in Nyang'oro op cit 98.

17 Idem 129

18 Glaser op cit 251-252.

13 For a comprehensive and authoritative account of the history of constitutionalism,
} 
between formal democracy on the one hand and substantive democracy on the other. Nor do individual, political and civil rights oppose the collective and socio-economic ones. ${ }^{19}$

All things considered, the different conceptions of democracy revolve around democracy as defined by US President Abraham Lincoln in his famous speech on 19 November 1863 referring to "the government of the people, by the people and for the people".

\section{Political Governance}

Governance is not a new concept. Like democracy and many other social sciences concepts, the concept of "governance" is quite controversial.

The UNDP defines governance as "the exercise of economic political and administrative authority to manage a country's affairs at all levels." 20 The World Bank defined governance "as the method through which power is exercised in the management of a country's political, economic and social resources for development."21 Governance includes a range of activities involving all cultural communities and various stakeholders in the country, government institutions, political parties, interest groups, non-governmental

see, for instance, McIlwain C H, Constitutionalism: Ancient and Modern (1947); Idem Constitutionalism in the Changing World (1939); Chandler, Enslen \& Renstrom op cit 3-67; Wormuth F D, The Origins of Modern Constitutionalism (1945); Friedrich C, Limited Government: A Comparison (1974); Idem Man and His Government (1963); Idem Constitutional Government and Politics (1937); Idem Constitutional Government and Democracy (1968).

14 Conac G, "Les processus de démocratisation en Afrique", in Conac G, (ed) L'Afrique en transition vers le pluralisme politique (1993) 11.

22 Arato A, "Dilemmas Arising from the Power to Create Constitutions in Eastern Europe", in Rosenfeld op cit 167-168.

23 Quoted by Nzombe S, Democracy, Human Rights and Constitutionalism in Post-Colonial Africa (1992) 1.

24 Armour L, "John Locke and American Constitutionalism", in Rosenbaum A S (ed), Constitutionalism: The Philosophical Dimension (1988) 10.

19 UNDP, "Governance for Sustainable Human Development," in UNDP Policy Document New York (1997) http://mirror.undp.org/magnet/policy (accessed July 7, 2011)

20 World Bank, "Governance" (Washington DC, 1993).

${ }^{21}$ George H. Fredrickson, The Spirit of Public Administration (Jossey-Bass, 1997) 86. 
organisations, the private sector and the public at large. ${ }^{22}$ Governance means different things to different people and its definition differs depending to whether one follows a liberal or narrow approach.

In its liberal sense, governance can be applied to a wide range of issues, relationships and institutions involved in the process of managing public and private affairs. In this sense the term enlarges and better illustrates what governments should be focussing on. Governance can then be political, economic or corporate.

The concept of "governance" progressively gained currency under the structural adjustments programmes (SAPs) that were devised and imposed on underdeveloped countries by international financial institutions such as the International Monetary Fund (IMF) and the World Bank in the 1970s. Under the SAPs, "governance" was primarily economic and corporate governance. When it turned political, it was not necessarily to be democratic as the international community and Western developed countries still supported the "dictatorships of development" in the Third World in general and in Africa in particular. ${ }^{23}$

This also explained why apartheid in South Africa enjoyed for decades the support by some of the most powerful actors of the international community, including three out of the five veto holders in the United Nations Security Council; namely France, the United Kingdom and the United States of America.

With the failure of "dictatorships of development" and the intensification of democratic struggles in the 1980s, there was a shift from authoritarian and bad governance to democratic and good governance. Good political governance had to be democratic governance and related to respect for human rights, including peoples' right to development, which was already enshrined in the African Charter for Human and Peoples' Rights that African leaders within the Organisation of African Unity (OAU) - now the African

22 See Mangu AMB, The Road to Constitutionalism and Democracy Post-Colonial Africa: The Case of the Democratic Republic of Congo (2002) UNISA at p48.

23 Assem Safieddine and Leila Atwi, "Is Governance a prerequisite for Democracy? Insights from the Middle East" Journal of Middle East Policy Council http:// www.mepc.org/journal/middle-east-policy-archieves/governance-prerequisitedemocracy (accessed July 17, 2011). 
Union (AU) - adopted during their summit held in Nairobi in June 1981. The African Charter finally came into force in October 1986 and it also aims at promoting good political governance which is closely related to democracy.

\section{Relationship Between Democracy and Governance}

According to Safieddine and Atwi, democratic societies should be defined by the adoption of political practices such as public debate, freedom of speech, elections, representation, transparency and accountability as well as consensus building and active decision making. ${ }^{24}$

Democracy is fundamentally rooted in the proposition that political authority is anchored in the will of the people.

Similarly, democratic governance implies governance based on fundamental and universally accepted principles including, accountability, participation, transparency, separation of powers, the rule of law, and respect for human rights. ${ }^{25}$

In the African and South African context following decades of colonial and neo-colonial authoritarianism and apartheid mismanagement, there is a close relationship between democracy and good political governance. This is stressed in many African instruments. For instance, the Constitutive Act of the African Union (Article $3(\mathrm{~g})$ ) provides that its objectives are inter alia to "promote democratic principles and institutions, popular participation and good governance".

Respect for democratic principles, human rights, the rule of law and good governance is also one of the basic principles of the African Union (Article 4 (m) African Union Constitutive Act). In the New Partnership for Africa's Development (NEPAD), African leaders also agreed that democracy and good governance were conditions

\footnotetext{
4 UNDP 1997, 7.

25 New Partnership for Africa's Development Declaration 71-85. In July 2002, they adopted the Declaration on Democracy, Political, Economic and Corporate Governance.
} 
for sustainable development and established a Democracy and Political Governance Initiative. ${ }^{26}$

At the inaugural African Union Summit held in Durban, South Africa, in July 2002, African leaders adopted the Declaration on Democracy, Political, Economic and Corporate Governance. ${ }^{27}$ The African Peer review Mechanism (APRM) was mandated to ensure that the policies and practices of participating states conform to the agreed political, economic and corporate governance values, codes and standards contained in this Declaration. ${ }^{28}$

Enduring democratic systems are characterised by meaningful political participation and peaceful competition, protection of human rights, lawful governance and strong democratic values. ${ }^{29}$ In a democratic state, the authority is derived from the people. The government should be legitimate. It should be based on their explicit consent as expressed during free and fair elections that help them chose those who should govern on their behalf and remain accountable to them in the exercise of their mandate. Without promotion of, respect for and a culture of human rights, there is no possibility for democracy. The struggle against apartheid in South Africa finally amounted to the struggle for democracy and good political governance.

\section{South Africa's Struggle for Democracy and Good Political Governance}

The history of the struggle for democracy and good political governance in South Africa can be divided into three periods; namely the period from colonialism to apartheid, the transitional period and the period post-apartheid.

26 Christof Heyns and Magnus Killander, Compendium of Key Human Rights Documents (South Africa: Pretoria University Law Press, 2006) 293-298.

27 African Peer Review Mechanism Document adopted at the $6^{\text {th }}$ summit of the NEPAD Heads of State and Government Implementation Committee in Abuja, Nigeria, March 2003.

28 USAID Policy, "Democracy and Governance" November 1999, Washington DC 1, http://www.usaid.gov/regions/afr/abic/guides.html (accessed on 2 February 2011)

29 Sonia Bendix, Industrial Relations in South Africa (South Africa: Juta and Company Ltd, 1992) 6. 


\section{South Africa from Colonisation to Apartheid: Historical and Political Background}

It is worth considering the historical and political background of South Africa in order to understand the origins and to highlight the scope and importance of the developments that have taken place as well as the current state of affairs in South Africa.

As Bendix pointed out, "history plays an important role in the shaping of individual attitudes and societal norms and institutions". ${ }^{30}$ According to Cardozo, "history in illuminating the past illuminates the present, and in illuminating the present, illuminates the future." 31 In Elias's words, "worthwhile study of the problem of government and politics of Africa must necessarily take account of its past forms of political, social and cultural organisations." ${ }^{32}$ In South Africa, colonisation started during the $16^{\text {th }}$ century, when the Dutch East India Company established a provisioning station at the Cape around $1652 .{ }^{33}$

30 Benjamin N. Cardozo, The Nature of the Judicial Process (New Haven: Yale University Press, 1921) 53.See also Budeli M, Freedom of Association and Trade Unionism in SA: From Apartheid to the Democratic Constitutional Order. South Africa: University of Cape Town, 2007 at 107.

31 Taslim O. Elias, Government and Politics in African Context (London: Asia Publishing House, 1963) 1.

32 On the colonial history of South Africa, see Martin A. Du Toit, South African Trade Union (Johannesburg: McGraw-Hill, 1976) 10-11; Martheanne Finnemore and Roux Van der Merwe, Introduction to Labour Relations in South Africa (Mayville : Butterworths 1996) 21-22; Edward Roux., Time Longer than Rope : A History of the Black Man's Struggle for Freedom in South Africa (Madison, Wisconsin: University of Wisconsin Press,1964); Harold J. Simons, Class and Colour in South Africa 1850-1950 (Harmondsworth, Middlesex : Penguin,1969); Johan Maree, The Independent Trade Unions 1974-1984 (Johannesburg: Ravern, 1987); Ivan L. Walker and Ben J. Weinbren, 2000 Casualties : A History of Trade Unions and Labour Movements in the Union of South Africa (South Africa: South African Trade Union Council, 1967) 2-3; Budeli M, Freedom of Association and Trade Unionism in SA: From Apartheid to the Democratic Constitutional Order. South Africa: University of Cape Town, 2007 at 106-150; Charles W. Stahl, "Migrant Labour Supplies, Past, Present and Future with Special Reference to the Gold-Mining Industry, " in Black Migration to South Africa, ed. Roger W. Bohning (Geneva: International Labour Office,1981) 7-8.

33 Martin Brassey, Employment and Labour Law Vol 1 (Cape Town: Juta, 1998) A1: 10-11. 
In subsequent decades, French Huguenot refugees, the Dutch, and Germans also began to settle in the Cape. Collectively, they formed the Afrikaner segment of the population. By 1779, European settlements extended throughout the Southern part of the Cape. The British gained control of the Cape of Good Hope at the end of the $18^{\text {th }}$ century. British settlement and rule marked the beginning of a long conflict between the Afrikaners and the English. ${ }^{34}$

At the beginning of 1836, partly to escape British rule and cultural hegemony and partly out of resentment at the recent abolition of slavery, many Afrikaner farmers (Boers) undertook a northern migration that became known as the "Great Trek". This movement brought them into contact and conflict with African groups in the area, the most formidable of which were the Zulus. Under their powerful leader, Shaka (1787-1828), the Zulus conquered most of the territory between the Drakensberg Mountains and the sea (now KwaZulu-Natal). ${ }^{35}$

In 1852 and 1854, the independent Boer Republics of the Transvaal and Orange Free State were created. Relations between these Republics and the British were strained. ${ }^{36}$ British forces prevailed during the Anglo-Boer wars of 1880-81 and 1899-1902 and the Boer Republics were incorporated into the British Empire.

In May 1910, the two Republics and the British colonies of the Cape and Natal formed the Union of South Africa, a self-governing dominion of the British Empire. The Union's Constitution kept all political power in the hands of the Whites. ${ }^{37}$

In 1912, the South African Native National Congress was founded in Bloemfontein and eventually became known as the African National Congress (ANC). Its goals were the elimination of restrictions

34 See Brassey 1998, Al: 14; Eddie Webster, Work and Industrialisation in South Africa: An Introductory Reader (Randburg, South Africa: Ravan Press, 1994) 52-53.

35 Howard G. Ringrose, The Law and Practice of Employment (South Africa: Juta 1983)5; Walker and Weinbren 1967, 2.

36 Walker and Weinbren 1967, 2; Finnemore and Van der Merwe 1996, 23-24.

37 For instance the Native Land Act 27 of 1913, Regulation of Wages, Apprentices and Improvers Act 29 of 1918, Native Urban Areas Act 21 of 1923, Industrial Conciliation (Amendment) Act 11 of 1924, Industrial Conciliation (Amendment) Act 24 of 1930 and Labour Relations Act 28 of 1956. 
based on colour and the enfranchisement of and parliamentary representation for blacks. Despite these efforts the government continued to pass laws limiting the rights and freedoms of blacks. ${ }^{38}$

South Africa's apartheid era began in 1948, when the National party (NP) won the all-white elections and began passing legislation codifying and enforcing an even stricter policy of white domination and racial separation". ${ }^{39}$

The Afrikaans word "apartheid" literally means "separation" or "apartness". In English, it came to mean any legally sanctioned system of ethnic segregation. The word "apartheid" was used by the National Party to protect the interests of the Whites in general and Afrikaners in particular. However, it must be pointed out that the Afrikaner nationalists did not invent apartheid. It was actually pioneered by the British colonial governments of Natal and the Cape long before the National Party came to power in 1948 and made it a national policy. ${ }^{40}$ Under the apartheid regime, Blacks were not represented within the political system. They were incorporated under their traditional leadership within areas they had been restricted to in the process of conquest. A flood of laws enacted to formally institute the dominance of white people over other races followed the coming of the National Party to power in $1948 .{ }^{41}$

The apartheid regime denied many human rights to the overwhelming majority of African people, especially their civil and political rights.

Under apartheid, the Black people were considered human beings of the second zone, just close to animals. They were not citizens, but subjects.

In 1961, the Republic of South Africa was proclaimed and a constitution was adopted. ${ }^{42}$ The apartheid government enforced the principle of parliamentary sovereignty. Parliament had sovereign

38 Bendix 1992, 6.

39 Budeli 2007 at 75.

40 Idem.

${ }^{41}$ Fundamental rights such as the right to freedom of association, freedom of assembly, the right to form and join political parties of own choice and to participate in the activities of such political party. Blacks were not even allowed to vote. The government created homelands and blacks had to have pass ....

42 Act 32 of 1961. 
legislative authority and had full powers to make the laws. ${ }^{43}$ Thus, no court of law had the authority to pronounce upon the validity of any Act passed by the parliament. The apartheid regime continued unabated but had now to face opposition from the black people organised to combat it in a number of political and social associations, prominently the ANC.

In 1983, South Africa had a new Constitution (Act 110 of 1983). Like its predecessors, the 1983 Constitution entrenched and enforced racial discrimination and classification, which was at the heart of apartheid. It maintained the exclusion of black majority outside of State politics as they were denied any political rights and the Cabinet comprised of non-white (coloured) member only.

However, from the beginning, the apartheid regime had to face challenges coming from the international community especially after the United Nations adopted the Universal Declaration of Human Rights in 1948, since it was based on the denial of virtually all-civil and political rights to the black people who constitute the overwhelming majority of the population in South Africa. However, it was still supported by some of the most powerful United Nations member states with the veto right in the Security Council. ${ }^{44}$ International challenges against apartheid intensified as more and more states in Asia, South America and the rest of Africa gained their independence and became members of the United Nations.

International and domestic challenges against apartheid reached their climax in the late 1980s. The apartheid or white regime faced a tremendous dilemma: reform or perish. It chose the latter, all political prisoners were released, including Nelson Mandela a prominent politician, by un-banning all antiapartheid organisations were unbanned and embarking on a negotiation process.

\section{Kempton Park Negotiations and South Africa's Transition from Apartheid to Democracy and Good Political Governance}

In 1989, FW De Klerk succeeded PW Botha as the president of South Africa. Soon after assuming office, FW De Klerk met with prominent black leaders and ordered the release of many political

43 See section 59 (1) of Act 32 of 1961.

44 France, the United Kingdom and the United States of America. 
prisoners. In February 1990, he ordered the release of Nelson Mandela who had been imprisoned for 27 years. Subsequently, negotiations began in Kempton Park regarding the transition from apartheid government to a democratic South Africa that would be based on equality, human dignity and fundamental freedoms. Delegations from 19 governmental and political organisations took part in these negotiations. These negotiations came to standstill when Chris Hani was assassinated on the $10^{\text {th }}$ of April 1993. Hani was the leader of the South African Communist Party, which is in a tripartite alliance with the ANC and Congress of South African Trade Unions (COSATU).

Propitiously, Nelson Mandela addressed the South African nation and restored peace in South Africa. Although the negotiations were suspended for several times due to violence, finally they ended with the adoption of a draft interim constitution containing a Bill of Rights enshrining the rights of all the people in the country.

\section{The Post-Apartheid Constitutional Order}

The draft interim constitution adopted during the Kempton Park negotiations on 22 December 1993 was tabled before the apartheid parliament which enacted it into law. This Constitution, which was a transitional constitution, entered into force on 27 April 1994. One of its major objectives was to provide for an interim government and set out the procedures for the negotiation and drafting of a "final" Constitution.

Elections were held in 1994. The ANC won these elections and Nelson Mandela became the first democratically elected President of the Republic of South Africa.

The 1996 Constitution (Act 108 of 1996) was passed and superseded the interim constitution. The new Constitution was promulgated by Nelson Mandela at Sharpeville on 10 December 1996 and came into effect on 4 February 1997. The aim of the 1996 Constitution as certified by the Constitutional Court ${ }^{45}$ was to "heal the divisions

45 See Certification of the Constitution of the Republic of South Africa 19961996 (10) BCLR 1253 (CC), which failed, and Certification of the Amended Text of the Constitution of the Republic of South Africa 19961997 (1) BCLR 1 (CC), in terms of which the 1996 Constitution was eventually certified as conforming 
of the past and establish a society based on democratic values, social justice, and fundamental human rights" and to "lay the foundations for a democratic and open society" (Preamble to the 1996 Constitution). This constitution provides that South Africa is a "democratic state" (Section 1 (d) read with Preamble, Sections 2, 7 (1) and 195 (1) of the 1996 Constitution) founded on "democratic values" including human dignity, the achievement of equality and the advancement of human rights and freedoms, non-racialism and non-sexism and the "supremacy of the Constitution" and the rule of law (Section 1 of 1996 Constitution).

The 1996 Constitution contains one of the world most progressive Bills of Rights, including social, economic, political and cultural rights. The separation of powers between the executive, the legislature and the judiciary is entrenched to avoid any return to authoritarianism like under apartheid. A number of institutions were also established to support democracy and good political governance. The institutions stipulated in Chapter 9 of the 1996 Constitution are the Public Protector, Human Rights Commission, the Commission for the Promotion and Protection of Rights of Cultural, Religious, and Linguistic Communities, the Commission for Gender Equality, the Auditor General and the Independent Electoral Commission.

All these institutions are independent from the state. They are subject to the Constitution and the law only. At the same time, they have to act impartially and exercise their powers and perform their functions without any fear, favour or prejudice. ${ }^{46}$

\section{Democracy and Good Political Governance in Post-Apartheid South Africa: A Balance Sheet}

An assessment of democracy and good political governance in postapartheid South Africa may be based on elections, respect for the rule of law, independence of the judiciary and the protection and promotion of the rights enshrined in the Bill of Rights and other human rights instruments binding on the Republic.

to the Constitutional Principles provided in Schedule 4 of the Constitution of the Republic of South Africa Act No 200 of 1993, according to Section 71 of the same Constitution.

46 Section 181 (2) of the 1996 Constitution. 


\section{Elections}

Free and fair elections are an important facet of democracy, constitutionalism and good governance. As mentioned earlier, the first South African democratic general elections were held on 27 April 1994. For the first time all South African citizens were entitled to cast their votes freely and without any fear. When the elections results were announced on 6 May 1994, the ANC fails to secure two thirds majority, and they had secured $62.6 \%$ votes. Thus, the ANC is not able to amend the Constitution without negotiating with other parties. These elections were also pronounced as free and fair by the international, regional as well as foreign observers. The election results marked the end of apartheid and the beginning of democracy and constitutionalism in South Africa.

In line with the 1996 Constitution, on 9 May 1994, the National Assembly was convened in Cape Town and unanimously elected Nelson Mandela as the first democratically elected president of the Republic of South Africa. President Mandela governed for a term of five years. At the end of his term, one of his deputy presidents, $\mathrm{Mr}$ Thabo Mbeki, took over as the president of the ANC and the country until September 2008 when he was recalled from presidency by the ANC. Mr Kgalema Motlante was then appointed interim president until new elections were held. The conduct of the 2008 elections were free and fair too. Once again the ANC won these elections and the National Assembly elected Jacob Zuma as the new country's president. His term is to end in 2013, but it is renewable if he is reelected. Provincial and local elections have also been regularly held in South Africa since 1994. Until now, South Africa provides one of the best practices when it come to election in the continent with regard to the organisation of regular, free and fair elections.

\section{Rule of Law and Independence of the Judiciary}

Democracy and good political governance also require respect for the rule of law and independence of the judiciary. The rule of law implies that the law reigns supreme and no one is above the law. Respect for the rule of law can be secured when there is an independent judiciary. 
The 1996 Constitution provides that the judicial authority of the Republic is vested in the courts. ${ }^{47}$ Courts are also independent and impartial, subject only to the Constitution and the rule of law, which they must apply without fear, favour or prejudice. The Constitution expressly provided that 'no person or organ of state may interfere with the functioning of the courts. ${ }^{38}$ The Judiciary is the guardian and watchdog of the Constitution. The highest court in constitutional matters is the Constitutional Court that has jurisdiction in all constitutional matters. Since the end of apartheid, the judiciary has played a crucial role in ensuring respect for the rule of law and in protecting and promoting human rights despite the threats that the Courts has to deal with. ${ }^{49}$

\section{Protection and Promotion of Human Rights}

The 1996 Constitution of the Republic of South Africa contains a Bill of Rights which is a cornerstone of democracy in South Africa. The Bill of rights enshrines the rights of all people in the country and affirms democratic values of human dignity, equality and freedom. ${ }^{50}$ Human dignity, equality and freedoms are the founding values of the South African Constitution. ${ }^{51}$

The South African Bill of Rights protects all the three "generations" of rights; namely civil and political rights as well as social, economic rights, and cultural rights. It protects both individual and collective rights.

The Constitutional Court has played a crucial role in enforcing these rights as can be demonstrated by its remarkable case law which has inspired many other courts and human institutions in the world. It is worth highlighting two land mark judgments related to the promotion of civil and political rights on the one hand and socioeconomic rights on the other hand. These judgments, which are the jewels of the

47 Section 165(1) of the 1996 Constitution.

48 Section 165(3).

49 Currently there has been a debate within the ruling party proposing the review of the powers of the Constitutional court due to the court's comments on some of the policies.

50 Section 7 (1) of the 1996 Constitution.

51 Section 1 of the 1996 Constitution. 
South African human rights jurisprudence, are $S$ v Makwanyane ${ }^{52}$ and Government of the Republic of South Africa $v$ Grootboom. ${ }^{53}$ In the Makwanyane case, the Constitutional Court championed the rights to life and human dignity and ruled on the unconstitutionality of the death penalty under the Interim Constitution of the Republic of South Africa. However, Grootboom remains the most important case with regard to the promotion of socioeconomic rights, especially the right to access to housing, health care, water and social security.

In Grootboom, the Constitutional Court had to consider the legality of the conduct of the local authority in evicting a group of squatters who had moved onto private land that had been earmarked for low-cost housing. A Magistrate's court had ordered the squatters to vacate the land on a certain date or face eviction.

However, the eviction under the control of the municipality, took place a day early and in circumstances which saw the squatters' homes demolished, their building materials and their possessions deliberately destroyed. The Constitutional court found that the government measures to provide housing were inadequate, since no provision was made for temporary shelter for homeless people. This omission was found to be unreasonable since it ignored those most in need. ${ }^{54}$ The court held that this was a violation of the negative obligation in section 26(1). ${ }^{55}$

The Bill of Rights also provides for popular participation in the process of governance by guaranteeing the right to access to information. The state must respect, protect, promote and fulfil the rights in the Bill of Rights (Section 7 (2) of the 1996 Constitution). However, the rights guaranteed are subject to limitations and the limitation should comply with the provisions of section 36 of the Constitution.

\footnotetext{
$52 \quad$ S v Makwanyane and Another 1995 (3) SA 391 (CC).

53 Government of the Republic of South Africa v Grootboom 2002 (11) BCLR 1169 (CC).

54 Government of the Republic of South Africa v Grootboom paragraph 44.

55 Ibid. paragraph 88.
} 


\section{Conclusion}

Since independence in 1912 and the establishment of apartheid in 1948, South Africa has made tremendous progress on the road to democracy and good political governance. South Africa has become by all standards one of the shining examples and employ best practices of democracy and good political governance on the African continent.

However, the APRM Report on South Africa ${ }^{56}$ stressed a number of challenges that South Africa need to overcome to consolidate democracy and good political governance. These challenges relate to the independence of the judiciary, which has been more than once under attack from some quarters of the ruling party; respect for human rights, including social and economic rights and the rights of the refugees and migrants; poverty that affects the majority of the population, especially the black people; corruption which is rampant in the public sphere, and crime.

The South African government responded that it was aware of the challenges and undertook to improve the quality of democracy and governance in the country. Based on the political will that exists, a vibrant civil society and the rising public awareness, the prospects for democracy and good political governance are very promising and better than in many African countries. However, incessant efforts should be made to ensure that democracy is consolidated to avoid any return to authoritarian rule that characterised the apartheid South Africa.

\section{Bibliography}

African Peer Review Mechanism (APRM), South Africa Country Review Report, 2009.

Beckman Björn, "Whose Democracy? Bourgeois versus Popular Democracy." Review of African Political Economy (1989): 84-98.

Bendix, Sonia. Industrial Relations in South Africa. South Africa: Juta and Company Ltd, 1992.

56 African Peer Review Mechanism, South Africa Country Review Report, 2009. 
Brassey, Martin. Employment and Labour Law Vol 1. Cape Town: Juta, 1998.

Budeli, Mpfariseni, Freedom of Association and Trade Unionism in SA: From Apartheid to the Democratic Constitutional Order. South Africa: University of Cape Town, 2007.

Cardozo, Benjamkin N. The Nature of the Judicial Process. New Haven: Yale University Press, 1921.

Du Toit, Martin A. South African Trade Union. Johannesburg: McGraw-Hill, 1976.

Elias Taslim O. Government and Politics in African Context. London: Asia Publishing House, 1963.

Finnemore Martheanne and Van der Merwe Roux. Introduction to Labour Relations in South Africa. Mayville: Butterworths 1996.

Fredrickson, George H. The Spirit of Public Administration. JosseyBass, 1997.

Heyns Christof and Killander Magnus. Compendium of Key Human Rights Documents. South Africa: Pretoria University Law Press, 2006.

Hinden, Rita. Africa and Democracy. London: Encounter Pamphlet Series, 1963.

Hoffman, John. State, Power, and Democracy: Contentious Concepts in Practical Political Theory. New York: St. Martins Press, 1988.

Maree, Johan. The Independent Trade Unions 1974-1984. Johannesburg: Ravern, 1987.

Mangu AMB, The Road to Constitutionalism and Democracy in Post-Colonial Africa: The Case of the Democratic Republic of Congo (2002) UNISA. 
NEPAD Declaration on Democracy, Political, Economic and Corporate Governance. http://www.uneca.org/aprm/documents/ book2.pdf (accessed July 18, 2011).

Nwabueze, Benjamin O. Constitutionalism in the Emergent States. London: C Hurst \& Co, 1973.

Nyang'oro, Julius E. "Discourses on Democracy in Africa: An Introduction." In Discourses on Democracy: Africa in Comparative Perspective, edited by Julius E. Nyang'oro Discourses. Tanzania: Dar-es-Salaam University Press 1996.

Ringrose Howard G. The Law and Practice of Employment. South Africa: Juta 1983.

Safieddine Assem and Atwi Leila, "Is Governance a prerequisite for Democracy? Insights from the Middle East" Journal of Middle East Policy Council http://www.mepc.org/journal/ middle-east-policy-archieves/governance-prerequisitedemocracy (accessed July 18, 2011).

Schochet, Gordon J. "Introduction: Constitutionalism, Liberalism, and the Study of Politics." In Constitutionalism, edited by Roland J. Pennock and William J. Chapman. New York: New York University Press, 1979.

Shivji, Issa G. "State and Constitutionalism: A New Democratic Perspective." In State and Constitutionalism: An African Debate on Democracy, edited by Issa G. Shivji. Harare: SAPES, 1991.

Simons Haraold J. Class and Colour in South Africa 1850-1950. Harmondsworth, Middlesex: Penguin, 1969.

Sklar, Richard L. "African Politics: The Next Generation." In State, Conflict, and Democracy in Africa, edited by Richard Joseph. Lynne Rienner Publishers, 1999.

Sono, Temba. Comments on Democracy and Its Relevancy to Africa. African Perspectives: Selected Works No.3, 1992. 
Roux Edward. Time Longer than Rope: A History of the Black Man's Struggle for Freedom in South Africa. Madison, Wisconsin: University of Wisconsin Press, 1964.

UNDP. “Governance for Sustainable Human Development." UNDP Policy Document New York (1997) http://mirror.undp.org/ magnet/policy (accessed July 7, 2011).

United Nations, Committee of Experts on Public Administration. "Definitions of Basic Concepts and Terminologies in Governance and Public Administration." 5 ${ }^{\text {th }}$ Session 27-31 March 2006 (E/c.16/2006/4).

USAID Policy. "Democracy and Governance." November 1999, Washington DC 10523 http://www.usaid.gov/regions/afr/ abic/guides.html (accessed February 2, 2011).

Venter, Francois. Constitutional Comparison. The Netherlands: Kluwer Law International, 2000.

Wiseman, John A. Democracy in Black Africa. Survival and Revival. New York: Paragon House Publishers, 1990.

Wiseman, John A. The New Struggle for Democracy in Africa. Avebury: Aldershot and Vermont, 1996. 